\title{
PROFILE OF ORTHODONTIC EDUCATION IN BRAZILIAN UNDERGRADUATE DENTISTRY COURSES
}

\author{
PERFIL DO ENSINO DE ORTODONTIA NOS CURSOS DE GRADUAÇÃO EM \\ ODONTOLOGIA NO BRASIL
}

\author{
Ana Maria Martins BRANDÃ ${ }^{1}$; Gustavo Antonio Martins BRANDÃO ${ }^{1}$; \\ Adriana Souza de JESUS ${ }^{1}$; Flávia Martão FLÓRIO² \\ 1. Department of Orthodontics, Federal University of Pará, Belém, Pará, Brazil; 2. Department of Public Health Dentistry, São Leopoldo \\ Mandic School of Dentistry and Research Center, Campinas, SP, Brazil. flavia.florio@ slmandic.edu.br
}

\begin{abstract}
New paradigms of Brazilian dental education involve orthodontics in the context of generalist professional formation, encouraging the recognition of teaching reality of this discipline in undergraduate courses in dentistry. This article discusses the orthodontics discipline in Brazilian dentistry undergraduate courses to identify the number of semesters offered, nomenclature, insertion model, content format and the performance of clinical practice in undergraduate education and its association with characterization variables of the discipline. Electronic questionnaires were sent to 203 dental schools, 55 public and 148 private, registered to the Federal Council of Dentistry in 2013 . The questionnaires were answered by 92 teachers of orthodontics, representing $45.3 \%$ of the existing dental undergraduate courses in Brazil: 55.4\% of which from private and $44.6 \%$ public schools. The findings of this research show that orthodontics teaching is present in all undergraduate courses analyzed, is a predominant and integrated subject in pediatric dentistry, addresses the contents in theoretical and practical form both in the laboratory and clinic, and assists children with deciduous and mixed dentition for diagnosis, prevention and interception of malocclusions. Egressed students are able to recognize orthodontic problems and direct these young patients to treatment. The presence of clinical practice was associated with the variables that denote greater investments of higher education institutions in professors, academic credentials and curricular matrix due to the integrality of the contents and course load distribution for the discipline.
\end{abstract}

KEYWORDS: Orthodontics. Dental Education. Undergraduate Medical Education.

\section{INTRODUCTION}

Orthodontics has been part of the official curricula of undergraduate courses since 1925 when the first school of dentistry was created. Initially, its contents were integrated with the discipline of "Prosthesis" later, to pediatric dentistry, in a discipline called "orthodontics and pediatric dentistry." Only after the extinction of these disciplines in 1968 the discipline of orthodontics was established and for many years operated in isolation from pediatric dentistry. In the educational field, few studies are available from Brazil that clearly address the evolution of orthodontic teaching in dental undergraduate courses (VILELA, 2007).

It is known that orthodontics, as with all clinical sciences of dentistry, has evolved from Flexner curricula which teaches subjects separately, from integrated curricula (FLEXNER, 1910). These changes were necessary to adapt the model of dental professionals' formation (MASETTO, 2006).

The incongruity between the profile of the orthodontic student's formation and society demands for orthodontic treatments has made the reformulation of public policies necessary for changing the existing oral health panorama (KORNIS; MACIEL, 2006). The decline in epidemiological rates of caries and the increasing prevalence of malocclusions, has led to the incorporation of orthodontic assistance in the public sector, making eminent the necessity to train professionals able to diagnose orthodontic problems (KORNIS; MACIEL, 2006, BARROSO, 2012).

The guidelines of the American Dental Association state that "graduates should be competent to recognize malocclusion in the primary, mixed and permanent dentition as well as follow the development of dentition and treat acquired abnormalities" (BEHRENTS; KLEIN, 2006).

In Brazilian educational dental programs, on the recommendation of the National Curriculum Guidelines (DCN) for Undergraduate Dentistry, orthodontics education should be inserted in pediatric dentistry with the purpose of integrating the particular aspects of pathology and pediatric clinic as well as the performance of orthodontic preventive measures (DCN-CNE / CES No. 1300/01) (BRAZIL, 2002).

In general, there is consensus on the role of undergraduate education to qualify future clinicians representing a workforce in oral health; however, few argue that at graduation a dentist must be able to recognize malocclusion, know to whom patients should be referred, and what stage of tooth 
development they are in. The appropriate referral of orthodontic treatment improves the overall quality of dentistry (MOORE; ERICKSON, 1988; O'BRIEN K; SPENCER J, 2015).

In Brazilian dental education, the orthodontics discipline's contribution to the formation of the general practitioner raises controversial questions about the system's capability to produce skilled practitioners. Observers question the development of the student's ability to recognize problems, make the correct diagnosis and whether they have the autonomy to perform procedures (MIGUEL et al., 2005; MIGUEL et al., 2008; BARROSO, 2012; CANAVARRO et al., 2012).

In view of this paradoxical scenario, the major contribution of this work is to recognize the educational reality of orthodontics in dentistry undergraduate courses, which can guide the development of guidelines for graduates' continuing education as we seek to define the exact role of training competent generalists to diagnose orthodontic problems.

\section{MATERIALS AND METHODS}

This work was approved by the Committee of Ethics for Research of São Leopoldo Mandic School of Dentistry and Research Center, under protocol number 2011/0442. The data collection was carried out by composing an electronic questionnaire developed and previously tested by the researchers, comprising 19 objective questions about orthodontics teaching at the undergraduate level, characterizing the amount of semesters offered, nomenclature, insertion model of the discipline, and content format, in addition to activities in the clinical practice setting and its relation to the characterization variables of the discipline.

Emails were sent with invitation letters to 203 directors of Brazilian dental schools, 55 public and 148 private, requesting the participation of orthodontics teachers that comprise the body of instructors in the discipline to answer the questionnaire. The consent form was made available on an emailed link sent weekly for three months. The sample of respondents consisted of 92 teachers $(n=92)$ representing $45.3 \%$ of the existing dental undergraduate courses in Brazil and $55.4 \%$ of the private and $44.6 \%$ public dental schools.

\section{RESULTS}

\section{Data concerning the sample}

Table 1 shows the results of features of the respondents of undergraduate courses in dentistry. The majority of the orthodontics teachers were male and the teaching experience was varied. The largest representation of teachers was from the Southeast region, followed by the Northeast. Proportionally, the Southeast had $37.6 \%$ of the represented courses, while in other regions at least half of the courses participated

In addition, we observed a balance in the participation of public institutions $41(44.6 \%)$ and private $51(55.4 \%)$. The majority [61 (66.3\%)] operated in integral regimens and $31(33.7 \%)$ in partial regimens. Schooling lasted five years in 61 $(66.3 \%)$ and 4 years in $31(33.7 \%)$ courses.

Table 1. Features of the respondents of undergraduate courses in dentistry

\begin{tabular}{lcc} 
Variables & Absolute frequency (n) & Relative frequency (\%) \\
\hline Gender & 33 & 35.9 \\
Female & 59 & 64.1 \\
Male & & \\
Teaching experience & 20 & 21.7 \\
0 ---- 5 years & 20 & 21.7 \\
5 --- 10 years & 18 & 19.6 \\
$10---$ 15 years & 14 & 15.3 \\
15 --- 20 years & 20 & 21.7 \\
$20---$ 25 years & & \\
Region & 11 & 12.0 \\
North & 20 & 21.7 \\
Northeast & 8 & 8.7 \\
Midwest & 35 & 38.0 \\
Southeast & & \\
\hline
\end{tabular}




\begin{tabular}{lcc}
\hline South & 18 & 19.6 \\
Region (Total courses) & & \\
North (20) & 11 & 55.0 \\
Northeast (39) & 20 & 51.3 \\
Midwest (15) & 8 & 53.3 \\
Southeast (93) & 35 & 37.6 \\
South (36) & 18 & 50.0 \\
\hline
\end{tabular}

Profile of undergraduate-level orthodontics teachers from the participating institutions

Table 2 shows that most institutions had up to three teachers comprising the discipline team, and at least 2 teachers on the team were male.
Twenty-six of them had earned a doctorate (28.3\%) and only $22.8 \%$ of the institutions had teachers without specialization in orthodontics that ministered the discipline.

Table 2. Number of teachers by gender, credentials and specialty in orthodontics comprising the teaching team in orthodontics programs

\begin{tabular}{|c|c|c|}
\hline Variables & $\begin{array}{l}\text { Absolute } \\
\text { frequency } \\
\text { (n) }\end{array}$ & $\begin{array}{c}\text { Relative } \\
\text { frequency } \\
(\%)\end{array}$ \\
\hline \multicolumn{3}{|c|}{ Number of teachers } \\
\hline One & 17 & 18.5 \\
\hline Two & 31 & 33.7 \\
\hline Three & 24 & 26.1 \\
\hline Four & 9 & 9.8 \\
\hline Five & 5 & 5.4 \\
\hline Six & 2 & 2.2 \\
\hline Seven & 4 & 4.3 \\
\hline \multicolumn{3}{|l|}{ Male teachers } \\
\hline One & 35 & 38.0 \\
\hline Two & 29 & 31.5 \\
\hline Three & 10 & 10.9 \\
\hline Four & 5 & 5.4 \\
\hline Five & 3 & 3.3 \\
\hline None & 10 & 10.9 \\
\hline \multicolumn{3}{|c|}{ Female teachers } \\
\hline One & 31 & 33.7 \\
\hline Two & 16 & 17.4 \\
\hline Three & 5 & 5.4 \\
\hline Four & 5 & 5.4 \\
\hline None & 35 & 38.1 \\
\hline \multicolumn{3}{|c|}{ Specialization as high degree } \\
\hline One & 15 & 16.3 \\
\hline Two & 9 & 9.8 \\
\hline Three & 4 & 4.3 \\
\hline Four & 1 & 1.1 \\
\hline None & 63 & 68.5 \\
\hline \multicolumn{3}{|c|}{ Master as high degree } \\
\hline One & 20 & 21.7 \\
\hline Two & 19 & 20.7 \\
\hline Three & 8 & 8.7 \\
\hline None & 45 & 48.9 \\
\hline \multicolumn{3}{|c|}{ Doctorate as high degree } \\
\hline One & 26 & 28.3 \\
\hline Two & 19 & 20.7 \\
\hline Three & 12 & 13.0 \\
\hline
\end{tabular}




\begin{tabular}{lcc}
\hline Four & 2 & 2.2 \\
Five & 6 & 6.5 \\
None & 27 & 29.3 \\
Free-teaching as high degree & & \\
One & 4 & 4.3 \\
Two & 2 & 2.2 \\
Four & 2 & 2.2 \\
None & 84 & 91.3 \\
Teacher without titling in orthodontics & & \\
Yes & 21 & 22.8 \\
No & 71 & 77.2 \\
& 92 & 100.0 \\
\hline
\end{tabular}

Table 3 shows that there was a variation in the number of teachers in clinical practice. Only $5.5 \%$ of the courses had just one teacher active in clinical practice, and $30.1 \%$ had five or more teachers performing clinical activities. The presence of up to two teachers with specialization in orthodontics in clinical activities was $72.6 \%$. The frequency of at least one professor specializing in pediatric dentistry in orthodontic clinical practice was $72.6 \%$ and at least one teacher presented credentials in another specialty was $21.9 \%$. Of those who said they did not possess credentials in orthodontics, only one was not a pediatric dentist.

Table 3. Number of teachers in clinical practice of orthodontics and their respective specialties in dentistry undergraduate courses

\begin{tabular}{lcc}
\hline Variables & $\begin{array}{c}\text { Absolute } \\
\text { frequency }(\mathrm{n})\end{array}$ & $\begin{array}{c}\text { Relative } \\
\text { frequency } \\
(\%)\end{array}$ \\
\hline $\begin{array}{l}\text { Teachers in clinical practice } \\
\text { One }\end{array}$ & 4 & 5.5 \\
Two & 15 & 20.5 \\
Three & 15 & 20.5 \\
Four & 17 & 23.3 \\
Five or more & 22 & 30.1 \\
Teachers specializing in orthodontics & & \\
One & 20 & 27.4 \\
Two & 33 & 45.2 \\
Three & 11 & 15.1 \\
Four & 5 & 6.8 \\
Five or more & 4 & 5.5 \\
Teachers specializing in pediatric dentistry & & \\
One & 9 & 12.3 \\
Two & 21 & 28.8 \\
Three & 13 & 17.8 \\
Four & 3 & 4.1 \\
Five or more & 7 & 9.6 \\
None & 20 & 27.4 \\
Teachers with other specialties & & \\
One & 6 & 8.2 \\
Two & 5 & 6.8 \\
Three & 1 & 1.4 \\
Four & 1 & 1.4 \\
Five or more & 3 & 4.1 \\
None & 57 & 78.1 \\
& 92 & 100.0 \\
\hline
\end{tabular}




\section{Insertion model, content format and performance in university extension}

The results described in Table 4 showed that the integration of orthodontics with pediatric dentistry occurs in $35.8 \%$ of dental schools. Isolated, orthodontics is taught in $33.7 \%$ and in mixed form (isolated and integrated) in $27.2 \%$ of the courses. Integration with "another discipline" occurred mainly with pediatric dentistry, but there were reports of integration with periodontics, integrated clinic, supervised internship, clinical cariology, patients with special needs, occlusion / temporomandibular dysfunction. In most courses, the discipline has theoretical approaches in laboratory and clinical practice. In most institutions, orthodontics discipline does not feature in university extension activities.

Orthodontics in clinical practice courses for undergraduates was reported by the majority of the study participants, in special during the children's integrated clinic.

Table 4. Insertion model, content format, realization of university extension activities of Orthodontics discipline in graduation; Orthodontics in clinical practice, number of semesters (periods) and type of clinical practice in orthodontics in dentistry undergraduate courses.

\begin{tabular}{|c|c|c|}
\hline Variables & $\begin{array}{l}\text { Absolute } \\
\text { frequency } \\
\text { (n) }\end{array}$ & $\begin{array}{l}\text { Relative } \\
\text { frequency } \\
(\%)\end{array}$ \\
\hline \multicolumn{3}{|l|}{ Insertion model in graduation } \\
\hline Isolate & 31 & 33.7 \\
\hline Integrated with Pediatric Dentistry & 33 & 35.8 \\
\hline Integrated with other discipline & 3 & 3.3 \\
\hline Mixed & 25 & 27.2 \\
\hline \multicolumn{3}{|l|}{ Orthodontics content format } \\
\hline Only theoretical & 3 & 3.3 \\
\hline Theoretical and laboratorial practice & 19 & 20.7 \\
\hline Theoretical + laboratorial and clinical practice & 70 & 76.0 \\
\hline \multicolumn{3}{|l|}{ University extension activities } \\
\hline Yes & 33 & 35.9 \\
\hline No & 59 & 64.1 \\
\hline \multicolumn{3}{|l|}{ Clinical practice in graduation } \\
\hline Yes & 73 & 79.3 \\
\hline No & 19 & 20.7 \\
\hline \multicolumn{3}{|l|}{ Number of semesters with clinic } \\
\hline One & 19 & 20.7 \\
\hline Two & 38 & 41.3 \\
\hline Three & 12 & 13.0 \\
\hline Four & 4 & 4.3 \\
\hline None & 19 & 20.7 \\
\hline \multicolumn{3}{|l|}{ Practice in children's integrated clinic } \\
\hline Yes & 53 & 57.6 \\
\hline No & 39 & 42.4 \\
\hline \multicolumn{3}{|l|}{ Practice in adult integrated clinic } \\
\hline Yes & 6 & 6.5 \\
\hline No & 86 & 93.5 \\
\hline \multicolumn{3}{|l|}{ Practice in specific orthodontic clinic } \\
\hline Yes & 27 & 29.3 \\
\hline No & 65 & 70.7 \\
\hline Total & 92 & 100.0 \\
\hline
\end{tabular}




\section{Orthodontics discipline in the clinical practice} setting

The demand of patients assisted by orthodontics programs as part of clinical care in undergraduate courses (Table 5) was constituted mostly of children with mixed dentition (78.3\%), followed by children with primary dentition $(58.7$
$\%$ ) and teenagers (20.7\%). Only $6.5 \%$ of the courses assisted adults.

Regarding the procedures performed by orthodontic students, as shown in Table 5, it was found that most undergraduate orthodontics courses conduct clinical activities in diagnosis (69.6\%), prevention (72 8\%) and interception (76.1\%). Only $15.2 \%$ perform activities in corrective orthodontics.

Table 5. Characterization of patient demand for orthodontic clinical practice in dentistry undergraduate courses and Type of procedures performed in orthodontic clinical practice in dentistry undergraduate courses.

\begin{tabular}{|c|c|c|}
\hline Variables & $\begin{array}{c}\text { Absolute } \\
\text { frequency } \\
(\mathrm{n})\end{array}$ & $\begin{array}{c}\text { Relative } \\
\text { frequency } \\
(\%)\end{array}$ \\
\hline \multicolumn{3}{|c|}{ Children in deciduous dentition } \\
\hline Yes & 54 & 58.7 \\
\hline No & 38 & 41.3 \\
\hline \multicolumn{3}{|c|}{ Children in mixed dentition } \\
\hline Yes & 72 & 78.3 \\
\hline No & 20 & 21.7 \\
\hline \multicolumn{3}{|l|}{ Teenagers } \\
\hline Yes & 19 & 20.7 \\
\hline No & 73 & 79.3 \\
\hline \multicolumn{3}{|l|}{ Adults } \\
\hline Yes & 6 & 6.5 \\
\hline No & 86 & 93.5 \\
\hline \multicolumn{3}{|l|}{ Other groups } \\
\hline Yes & 0 & 0.0 \\
\hline No & 92 & 100.0 \\
\hline \multicolumn{3}{|l|}{ Diagnostic procedures } \\
\hline Yes & 64 & 69.6 \\
\hline No & 28 & 30.4 \\
\hline \multicolumn{3}{|l|}{ Preventive procedures } \\
\hline Yes & 67 & 72.8 \\
\hline No & 25 & 27.2 \\
\hline \multicolumn{3}{|c|}{ Interceptative procedures } \\
\hline Yes & 70 & 76.1 \\
\hline No & 22 & 23.9 \\
\hline \multicolumn{3}{|l|}{ Corrective procedures } \\
\hline Yes & 14 & 15.2 \\
\hline No & 78 & 84.8 \\
\hline Total & 92 & 100.0 \\
\hline
\end{tabular}


Presence of the discipline in undergraduate education and the role of orthodontics in the profile of students' professional development

Table 6 shows an association between conducting clinical practice $(p<0.05)$ and the amount of semesters offered in the discipline, more teachers on the team, teachers with advanced credentials, integration of orthodontics with other disciplines, contents approach, and the role of the discipline in the students profiles.

Table 6. Association of orthodontics performance in clinical practice of dentistry undergraduate courses with characterization variables of the discipline in undergraduate courses

\begin{tabular}{|c|c|c|c|c|}
\hline \multirow[b]{2}{*}{ Variables } & \multicolumn{2}{|c|}{ Clinical practice } & \multirow[b]{2}{*}{$\begin{array}{l}\text { Total } \\
\mathrm{N}(\%)\end{array}$} & \multirow[b]{2}{*}{$p$-value } \\
\hline & $\begin{array}{c}\text { Yes } \\
\text { Absolute } \\
\text { frequency } \\
\text { (n) }\end{array}$ & $\begin{array}{c}\text { No } \\
\text { Relative } \\
\text { frequency } \\
(\%)\end{array}$ & & \\
\hline \multicolumn{5}{|l|}{ Number of semesters of orthodontics } \\
\hline One & $6(8.2)$ & $13(68.4)$ & $19(20.7)$ & $0.000^{\dagger}$ \\
\hline Two & $34(46.6)$ & $5(26.3)$ & $39(42.3)$ & \\
\hline Three & $19(26.0)$ & $1(5.3)$ & $20(21.7)$ & \\
\hline Four & $10(13.7)$ & $0(0.0)$ & $10(10.9)$ & \\
\hline Five & $3(4.1)$ & $0(0.0)$ & $3(3.3)$ & \\
\hline Six & $1(1.4)$ & $0(0.0)$ & $1(1.1)$ & \\
\hline \multicolumn{5}{|l|}{ Number of teachers } \\
\hline One & $9(12.3)$ & $8(42.1)$ & $17(18.5)$ & $0.005^{\dagger}$ \\
\hline Two & $26(35.6)$ & $5(26.3)$ & $31(33.7)$ & \\
\hline Three & $22(30.1)$ & $2(10.5)$ & $24(26.1)$ & \\
\hline Four & $9(12.3)$ & $0(0.0)$ & $9(9.8)$ & \\
\hline Five & $5(6.8)$ & $0(0.0)$ & $5(5.4)$ & \\
\hline Six & $1(1.4)$ & $1(5.3)$ & $2(2.2)$ & \\
\hline Seven & $1(1.4)$ & $3(15.8)$ & $4(4.3)$ & \\
\hline \multicolumn{5}{|l|}{ Teachers with doctorate as high degree } \\
\hline One & $21(28.7)$ & $5(26.3)$ & $26(28.3)$ & $0.023^{\dagger}$ \\
\hline Two & $18(24.7)$ & $1(5.3)$ & $19(20.7)$ & \\
\hline Three & $12(16.4)$ & $0(0.0)$ & $12(13.0)$ & \\
\hline Four & $1(1.4)$ & $1(5.3)$ & $2(2.2)$ & \\
\hline Five & $3(4.1)$ & $3(15.8)$ & $6(6.5)$ & \\
\hline None & $18(24.7)$ & $9(47.3)$ & $27(29.3)$ & \\
\hline \multicolumn{5}{|l|}{ Insertion model of the discipline } \\
\hline Isolate & $18(24.7)$ & $13(68.4)$ & $31(33.7)$ & $0.004^{\dagger}$ \\
\hline Integrated to Pediatric Dentistry & $28(38.3)$ & $5(26.3)$ & $33(35.8)$ & \\
\hline Integrated with other discipline & $3(4.1)$ & $0(0.0)$ & $3(3.3)$ & \\
\hline Mixed & $24(32.9)$ & $1(5.3)$ & $25(27.2)$ & \\
\hline \multicolumn{5}{|l|}{ Orthodontics content format } \\
\hline Only theoretical & $1(1.4)$ & $2(10.5)$ & $3(3.3)$ & $0.000^{\dagger}$ \\
\hline Theoretical and laboratorial practice & $4(5.5)$ & $15(79.0)$ & $19(20.7)$ & \\
\hline $\begin{array}{l}\text { Theoretical + laboratorial and clinical } \\
\text { practice }\end{array}$ & $68(93.1)$ & $2(10.5)$ & $70(76.0)$ & \\
\hline \multicolumn{5}{|l|}{$\begin{array}{l}\text { Role of the discipline in the student } \\
\text { formation profile }\end{array}$} \\
\hline Basic diagnosis of problems & $64(87.7)$ & $11(57.8)$ & $75(81.5)$ & $0.018^{\dagger}$ \\
\hline Need specialization & $7(9.6)$ & $4(21.1)$ & $11(12.0)$ & \\
\hline Insufficient time for training & $2(2.7)$ & $3(15.8)$ & $5(5.4)$ & \\
\hline No opinion about training profile & $0(0.0)$ & $1(5.3)$ & $1(1.1)$ & \\
\hline Total & $73(100.0)$ & $19(100.0)$ & $92(100.0)$ & \\
\hline
\end{tabular}

Test G probability 


\section{DISCUSSION}

The absence of patterning in orthodontics teaching of Brazilian undergraduate courses happens because the National Curriculum Guidelines for dental school courses are only a recommendation because in Brazil, colleges enjoy university autonomy, which defines their prerogative to make their curricula (CECCIM; FEUERWERKER, 2004).

The presence of orthodontics discipline in the undergraduate curricula of all institutions participating in this research reiterates the solid insertion of this specialty. Its insertion profile has gone through several changes since the creation of the first College of Dentistry, adapting to the changes that have occurred over 98 years in dental education from the extinction of the minimum curriculum in 1968 to the implementation of the National Curriculum Guidelines in 2001 (VILELLA, 2007; BRAZIL, 2002a).

Orthodontics lacks uniformity regarding its nomenclature, number of semesters, number of teachers, content format and its standardization, and even the insertion model, according to most studies on orthodontic undergraduate education in the existing literature (HAAG; FERES, 1999; BARROSO, 2012; MIGUEL et al., 2008), which, according to Cohen (1957), reflects a natural consequence of the historically controversial development of orthodontic as well as dental education.

The nomenclature variation defining the orthodontics discipline, independent of whether the school is public or private as reported by Haag (1999), confirms the findings of this sample, where the same variation was found. However, in most of the participating institutions, the discipline still denotes orthodontics.

Regarding the insertion model, content format and performance in university extension courses, The Brazilian Group of Orthodontics and Pediatric Dentistry Teachers has always raised the standards for work in the systematization and integration of teaching in the disciplines of orthodontics and pediatric Dentistry (MUNDSTTOCK et al., 2014).

The variation in the insertion model of orthodontics discipline as verified in this sample, according to Masetto (2006), occurs due to the curriculum flexibility and provides benefits that engage teachers in the construction of teaching and learning processes guided by the interdisciplinary paradigm. Training new dentists to face the current realities of dental practice should be the major objective.

The disciplinary integration, recommended in the curricular guidelines, inserts orthodontics teaching into pediatric dental clinic, resulting in an integrated children's clinic (BRAZIL, 2002a). This is a concept of holistic education, so that dental practitioners are able to attend the young public in an integral way.

Despite having been established in undergraduate curricula, theoretical and laboratory teaching has been conducted to the detriment of practical performance in clinical settings. The current pedagogical approach of presenting content within theory, laboratory and clinical practice is evident in $76 \%$ of the participating schools, highlighting the changes that have taken place in orthodontics teaching in accordance with the NCG. The results also showed that orthodontics does not feature in university extension activities; this unfortunate reality provides little opportunity for student contact with the local population (KRIGER; MORITA, 2004).

Concerning the role of orthodontics in the profile of orthodontic formation of the student, most of the responding teachers of this research stated that students of their institutions would be able to perform basic diagnostics of orthodontic problems $(87.7 \%)$. Moreover, in the current study, regarding the type of procedures performed in orthodontic clinical practice in dentistry undergraduate courses, the results showed that $69,6 \%$ were diagnostic procedures, $72,8 \%$ were preventive procedures and $76,1 \%$ were interceptative procedures. Despite this statement, it is clear from the literature that orthodontic education programs suffer to answer concerns about dental school graduates' ability to fill their professional role. Observers have questioned the development of graduates' ability to recognize orthodontic problems, make diagnoses, and have the autonomy to perform procedures (MIGUEL et al., 2005; MIGUEL et al., 2008; BARROSO, 2012; CANAVARRO et al., 2012).

According to Barroso (2012), most student respondents reported they were able to identify malocclusion in all the teething stages in patients treated in any clinic. Canavarro et al. (2012) related the inability to identify malocclusion as a problem for future clinicians to solve in orthodontic undergraduate courses. In sum, there is controversy over what should be taught, ranging from the ability to recognize problems and diagnose them to the need for autonomy to perform the procedures. Moreover, according to Kornis and Maciel (2006), the teaching of orthodontics in undergraduate 
courses should contribute to the formation of a generalist. The professional instruction for the student cannot be restricted to the treatment of occlusion disorders, ignoring the social context and the integral needs of patients (KRIGER \& MORITA, 2004).

Orthodontic care provided in children's clinics of Brazilian colleges, evidenced by the results of this research, resembles the philosophy of the pre-orthodontic program described by Araújo (1986) in which undergraduate students assist children by performing preventive and interceptive procedures This can be considered a viable practice for promoting oral health practices.

In the matter of demand of patients, orthodontic students attend children in undergraduate clinics who have deciduous $(58.7 \%)$ and mixed (78.3\%) dentition. Hebling (2006) recommends the offers of preventive and interceptive orthodontic services should be structured through a defined program (determining which malocclusions should be treated and how old the patient should be who receives services). In terms of age, he proposes that children must be in primary dentition or early mixed dentition to receive early treatment.

The role of orthodontics in children's clinics is described by the American Academy of Pediatric Dentistry (AAPD, 2005) that highlights the importance of managing the development of the dentition and occlusion and its effects on the wellbeing of children and adolescents. This management includes the recognition, the diagnosis, and the appropriate treatment of all stages of primary and mixed dentition (BERNAS et al., 2007).

Regarding the association of orthodontic clinical practice with characterization variables of the discipline, the results of this research revealed that ability to recognize orthodontic problems was associated with the presence of clinical practice $(87.7 \%)$. This fact is confirmed by studies showing the benefits of teaching in clinical practice is essential to prepare students because of the clinical training received during the course of study (HUNTER; CHAUDHRY, 2009; HONEY et al., 2011; KEEVE et al. 2012). Clinical experience gives students more competence to perform the procedures required in their professional practice that results in more confident graduates.

Despite the limitations of this type of study with questionnaires, the response rate was quite high, with results reflecting the uniformity of orthodontics teaching profile in the country. Future studies demonstrating what is developed in clinical practice of orthodontics and the vision of dentistry students and if they are really able to recognize orthodontic problems and directs them, are now needed to add to the results obtained by our study.

\section{CONCLUSIONS}

Orthodontics education is present in all undergraduate programs analyzed, is predominantly integrated with pediatric dentistry, addresses the contents in theoretical and practical ways both in the laboratory and clinic, and assists children with deciduous and mixed dentitions for diagnosis, prevention and interception of malocclusions.

The presence of clinical practice was associated with variables that denote big investments of the institution in credentialed teachers and in its curricular matrix by the integrality of the contents and distribution of workload for the discipline. Among the relevant information collected in this research, we can cite the positioning of teachers on the education profile of the student, where most claim they are forming dentists able to recognize orthodontic problems.

The association of practice with the student professional profile, as it requires a greater number of teachers on the team, performance in the largest number of semesters, and integral and integrated insertion, independent of whether the school is public or private. The action in clinical practice can be considered a challenge to the growth of the orthodontics discipline in Brazil.

RESUMO: Os novos paradigmas da educação Odontológica no Brasil envolvem a Ortodontia no contexto de formação do profissional generalista, instigando o reconhecimento da realidade educacional desta disciplina nos cursos de graduação em Odontologia. Este artigo aborda a situação do ensino da disciplina de Ortodontia nos cursos de graduação em Odontologia do Brasil, buscando identificar a quantidade de semestres de oferta, nomenclatura, modelo de inserção, formatação dos conteúdos, além da atuação no cenário das práticas clínicas de ensino de graduação e sua associação com as variáveis de caracterização da disciplina. Foram enviados questionários eletrônicos às 203 Faculdades de Odontologia sendo 55 públicas e 148 privadas registradas no Conselho Federal de Odontologia em 2013. Os questionários foram respondidos por 92 professores de Ortodontia, representando 45,3\% dos cursos de graduação de Odontologia existentes no Brasil, sendo 55,4\% particulares e 44,6\% públicas. O ensino de Ortodontia está presente em todos os cursos de graduação analisados, inserido predominantemente como disciplina integrada à Odontologia infantil, abordando os conteúdos de forma teórico prática, tanto em laboratório quanto em clínica, assistindo crianças na dentadura decídua e mista para 
diagnóstico, prevenção e interceptação das más oclusões, formando egressos aptos a reconhecer os problemas de Ortodontia e encaminhá-los para tratamento. A presença de prática clínica mostrou-se associada às variáveis que denotam maior investimento da instituição de ensino superior no corpo docente e sua titulação e na matriz curricular, pela integralidade dos conteúdos e distribuição de carga horária para a disciplina.

PALAVRAS-CHAVE: Ortodontia. Ensino em Odontologia. Ensino na Graduação.

\section{REFERENCES}

AMERICAN ACADEMY OF PEDIATRIC DENTISTRY (AAPD). Clinical guideline on management of the developing dentition and occlusion in pediatric dentistry. Chicago (IL): American Academy of Pediatric Dentistry (AAPD); 2005. 18 p.

ARAÚJO, M. C. M. Ortodontia para Clínicos: Programa Pré-Ortodôntico. 3a ed. São Paulo: Santos; 1986

BARROSO, M. C. F. Percepção de alunos sobre Ortodontia na graduação e a formação do clínico-geral . 92f. Dissertação (Mestrado). Departamento de Saúde Coletiva. Faculdade de Odontologia da Universidade Federal de Minas Gerais; 2012.

BEHRENTS, R.G; KLEIN, R. G. Education, research, and personnel needs in orthodontics. Current opinion in dentistry, v. 1, n. 5, p. 652-656, 1991.

BERNAS, A. J; BANTING, D. W.; SHORT, L. L. Effectiveness of phase I orthodontic treatment in an undergraduate teaching clinic. Journal of dental education, v. 71, n. 9, p. 1179-1186, 2007.

BRASIL. Ministério da Educação. Secretaria de Educação Superior. Diretrizes curriculares para os cursos de graduação. CNE. Resolução CNE/CES 3/2002. Diário Oficial da União, Brasília, 4 de março de 2002. Seção 1, p. 10. Brasília, DF, 1998. 2002a.

BRASIL. Ministério da Educação. Diretrizes Curriculares Nacionais dos Cursos de Graduação em Farmácia e Odontologia. Parecer CNE/CES nº 1.300/01, aprovado em 6 de novembro de 2001. Brasília: Ministério da Educação; 2002b

CANAVARRO, C.; MIGUEL, J. A. M.; QUINTÃO, C. C. A.; TORRES, M. F. M.; FERREIRA, J. P. M, BRUNHARO, I. H. V. P. Assessment of the orthodontic knowledge demonstrated by dental school undergraduates: recognizing the key features of Angle Class II, Division 1 malocclusion. Dental Press Journal of Orthodontics, v. 17, n. 1, p. 52-61, 2012. https://doi.org/10.1590/S2176-94512012000100008

CECCIM, R. B.; FEUERWERKER, L. C. M. Changes in undergraduate education in the health professions from the perspective of comprehensive training. Cadernos de Saúde Pública, v. 20, n. 5, p. 1400-1410, 2004.

COHEN, M. The teaching of undergraduate orthodontics at the Harvard School of Dental Medicine. American Journal of Orthodontics, v. 43, n. 2, p. 120-128, 1957. https://doi.org/10.1016/0002-9416(57)90221-X

FLEXNER, A. Medical Education in the United States and Canada. Bulettin number four. New York: Carnegie Foundation for the advancement of teaching; 1910.

O'BRIEN, K.; SPENCER, J. A viewpoint on the current status of UK orthodontic education and the challenges for the future. British Dental Journal, v. 218, n. 5, p. 181-183, 2015. https://doi.org/10.1038/sj.bdj.2015.50

HAAG, C. A.; FERES, M. A. L. Aspectos éticos e legais da Ortodontia no Brasil. Ortodontia, v. 32, n. 3, p. 67-81, 1999. 
HEBLING, S. R. F. Ortodontia e a Saúde Coletiva: Epidemiologia e Protocolo de assistência ortodôntica em saúde coletiva.100p. Dissertação (mestrado). Departamento de Saúde Coletiva. Faculdade de Odontologia da Universidade Estadual de Campinas; 2006.

HONEY, J.; LYNCH, C. D.; BURKE, F. M.; GILMOUR, A. S. Ready for practice? A study of confidence levels of final year dental students at Cardiff University and University College Cork. European Journal of Dental Education, v. 15, n. 2, p. 98-103, 2011. https://doi.org/10.1111/j.1600-0579.2010.00646.x

HUNTER, M. L.; CHAUDHRY, U. Paediatric dentistry in outreach settings: an essential part of undergraduate curricula? European Journal of Dental Education, v. 13, n. 4, p. 199-202, 2009.

https://doi.org/10.1111/j.1600-0579.2009.00574.x

KEEVE, P. L.; GERHARDS, U.; ARNOLD, W. A.; ZIMMER, S.; ZÖLLNER, A. Job requirements compared to dental school education: impact of a case-based learning curriculum. GMS Zeitschrift für medizinische Ausbildung, v. 29, n. 4, 2012.

KORNIS, G. E. M.; MACIEL, S. M. Orthodontics in oral public health policies: an example of equity in Juiz de Fora Federal University. Physis: Revista de Saúde Coletiva, v. 16, n. 1, p. 59-81, 2006.

KRIGER, L.; MORITA, M. C. Mudanças nos cursos de Odontologia e a interação com o SUS. Revista da ABENO, v. 4, n. 1, p. 17-21, 2001.

MASETTO, M. T. Um paradigma interdisciplinar para a formação do cirurgião-dentista. In: Carvalho ACP, Kriger L. Educação Odontológica. São Paulo: Artes Médicas; 2006. p. 31-50.

MIGUEL, J. A. M.; BRUNHARO, I. P.; ESPERÃO, P. T. G. Normal occlusion during mixed dentition: recognition of occlusal traits by dental students. Revista Dental Press de Ortodontia e Ortopedia Facial, v. 10, n. 1, p. 59-66, 2005.

MIGUEL, J. A. M.; CANAVARRO, C.; FERREIRA, J. P. M.; BRUNHARO, I. H. P.; ALMEIDA, M. A. O. Class III malocclusion diagnosis by graduation students. Revista Dental Press de Ortodontia e Ortopedia Facial, v. 13, n. 6, p. 118-127, 2008.

MOORE, R. N.; ERICKSON, L. C. Predoctoral and Continuing Education in Orthodontics: Opinions of Nebraska Alumni. Journal of clinical orthodontics: JCO, v. 22, n. 3, p. 152-156, 1988.

MUNDSTTOCK, C. A.; CARVAlHO, L. S.; FERES, M. A. A história da Ortodontia. In: Abrão J, Horliana RF, Shimizu RH. Ortodontia preventiva diagnostico e tratamento. São Paulo: Artes Médicas; 2014. p. 1-7.

VILELLA, O. V. Development of Orthodontics in Brazil and in the world. Revista Dental Press de Ortodontia e Ortopedia Facial, v. 12, n. 6, p. 131-156, 2007. 